\title{
Rhodes Must Fall: Archives and Counter-Archives
}

\section{Cynthia Kros}

Research Associate, Wits History Workshop and Research Associate, Capital Cities Programme, University of Pretoria

Email address: Cynthia.kros@yahoo.com

\section{Abstract}

This article takes its departure point from the fact that the VIADUCT 2015 platform overlapped chronologically with the "Rhodes Must Fall" campaign at the University of Cape Town (UCT). I ask whether bringing some of the archival theory that was discussed and applied at the platform to bear on an analysis of the campaign against the statue of Rhodes at UCT - in conjunction with the existing literature around monuments - is helpful in deepening understandings of the campaign. After singling out some of the most interesting literature on monuments and monumental iconoclasm, I explore the ways in which Derridean and Foucauldian inspired readings of the archive might be applied to the colonial memorial landscape. I propose that the campaign was sustained both by a substantial archive of iconoclasm, and that the protesters consciously tried to extend and elaborate on the archive/counter-archive.

\section{Keywords}

Rhodes, monuments, memorials, iconoclasm, photographic tropes, visual archive

\section{Introduction}

My article is inspired by the recent "Rhodes Must Fall" (hereafter "RMF") campaign at the University of Cape Town (UCT), which culminated in the removal of the statue of notorious mining magnate and British imperialist Cecil John Rhodes from the campus on the $9^{\text {th }}$ of April 2015. The VIADUCT 2015 platform entitled "Archival addresses: photographies, practices, positionalities" convened by the Visual Identities in Art and Design Research Centre at the University of Johannesburg (18-20 March) was contemporaneous with the UCT campaign, and has prompted a reading of it through the multifocal lenses of archive and counterarchive offered by VIADUCT participants. In her opening address at the platform, Carolyn 
Hamilton (2015) invited participants to think of the archive or archives in several senses, including as a 'large scale epistemological concept', with the power to constitute knowledge and disciplinary authority. Ann Laura Stoler (2002) warns against being fooled into thinking that the archive is merely a passive institutional repository for accommodating the predilections of either serious historians or antiquarians. Stoler (2002: 93) explores and exemplifies the apparently innocuous archive's intimate, enabling relationship with state power, and following Michel Foucault (1972), the limitations it places on 'what can be said.'

In light of the understanding of the archive's fundamentally active role in boosting and implementing state power, Hamilton (2015) and Verne Harris (2015) advocate 'epistemological banditry' or 'disobedience'. They call for an undermining of the established hierarchies of the archive, comprising those who are given voice and those who are silenced - and to rupture what Hamilton (2015) refers to as the 'knowledge silos' operating to preserve the purity of academic disciplines that have adhered to the archive's strictures about what constitutes "true" knowledge. I ask what would happen if, drawing on intermingling disciplinary streams issuing from the punctured silos, one applies principles of the "archive" to the memorial landscape that usually goes by other names, or conceded, through looking at them from another angle, that some of the archive's most effective users include students.

As a long-term scholar who has made extensive forays into the historical archive, and a heritage specialist interested in monumentality as well as theoretical debates around the nature of the archive, I have been watching the RMF campaign with a mixture of delight and unease. I am not sure whether I can accept iconoclasm as general practice. But the attack on this particular monument is, perhaps, a special case. It goes to the heart of what is disabling about a certain kind of institutional culture, as well as providing the locus for a media event that may be nothing more than spectacle, but may also leave an indelible impression of the pain that is the legacy of exclusionary politics.

The student leaders of the campaign were generally articulate about why they were calling for the fall of Rhodes. Ramabina Mahapa (2015), President of UCT's Students' Representative Council (SRC), states that the campaign was not directed against a particular historical individual, but rather the 'symbols' of 'institutional colonialism' that persist at the university well beyond the advent of democracy. Nevertheless, many observers and 
commentators were shocked by the students' vociferous calls to be rid of the Rhodes statue, as if it were a discourteous reaction to the generosity of their benefactor (see Petersen 2015), or a result of their historical ignorance.

Generally, commentators failed to understand that the RMF campaign was not intended (at least by its most vocal leaders and spokespeople) to deny a particular history. ${ }^{1}$ If they had borrowed from archival theory, commentators might have seen that the Rhodes statue had been "fashioned" with great deliberation, informed by an unambiguous political agenda (see Stoler 2002: 89). Many of the students knew, perhaps from having to pass it every day, from their readings of Frantz Fanon and Stephen Bantu Biko, or from dissident intellectuals, that this manufactured historical narrative of which the statue was the most conspicuous feature in their immediate environment, far from being of no great consequence after the retreat of the formal Empire, continues to exercise power over the present (see Ndebele 2013).

The scenes that played out around the statue ending with it being hoisted by crane onto a flatbed truck surrounded by students cheering its banishment, are evocative of the scene in Sergei Eisenstein's quasi-documentary film October: Ten Days that Shook the World (1928), in which the statue of Tsar Alexander III is toppled by revolutionaries, marking the 'proletariat's first victory on the road to socialism', according to the subtitle. One of the videos of the Rhodes statue's fall from grace (Holder 2015), almost mimics Eisenstein's montage, cutting between the statue swinging precariously from the crane, and cheering students raising cell phone cameras, with bare armed salutes and banners instead of the gun barrels and sickles heaving against the sky visible in Eisenstein's cutaways. ${ }^{2}$

Indeed, the visual record of the RMF campaign suggests indebtedness to the cinematic and photographic archive of iconoclasm. A student told UCT historian Rebecca Hodes that seeing off the Rhodes statue was like the toppling of Saddam Hussein's statue at the beginning of the Iraq War. Her observation suggests that she has retained a visual image that was disseminated around the world, and had absorbed the "western" media message that it signalled the righteous destruction of tyranny (Hodes 2015; see also Gye 2015). If the student were too young to have seen the image when it was originally distributed, she might have seen it in articles or programmes reflecting on its destruction on the occasion of the tenth anniversary two years ago. In the same month as the RMF campaign three statues of communist leaders were toppled in Ukraine - presumably by people resisting the Russian 
advance into that country (artdaily 2015). It is reasonable to suppose that the UCT protesters might have been influenced by the proliferation of iconoclastic imagery over the last two and a half decades, including that of monuments destroyed or removed as the Soviet Union disintegrated, recalled in commemorative programmes in 2014 for the twentyfifth anniversary of the Fall of the Berlin Wall (see Taylor 2011). A more disturbing thought is that the student protesters may also have been inspired by the media coverage of the artefacts and sites destroyed in Mali, Syria, Libya and Iraq between 2012 and the present by saboteurs associated with Al Queda or Islamic State.

The world has become much more saturated with visual imagery than it was when Susan Sontag (2001 [1977]: 23) was writing in the 1970s about 'image-junkies' and, given major advances in camera technology and digitisation, is more able to satisfy the junkies' cravings. The protesters, as the forest of cell phones and other photographic apparatuses captured in wide-angle shots of the campaign suggest, were probably in a position to draw on the substantial archive of iconoclasm, and to create their own. The latter is still in circulation along the seemingly endless pathways of social media, and through the intersections provided by facilities available in the mainstream media for sharing images on digital platforms. It is a rambunctious and, perhaps unquantifiable archive or counter-archive (in the sense of an archive that makes previously silenced voices audible), completely antithetical to the conventional notion of inventoried files reposing in a tranquil, dedicated physical space.

Does bringing broader notions of archive to an interpretation of South Africa's memorial landscape, as well as to visual representations of the RMF campaign enhance understandings of the event? In this paper I explore the ways in which it might. In the first section, I implicitly refer to a Foucauldian derived notion that power determines the production and recognition of knowledge, which has long informed the work of some VIADUCT participants (see Hamilton, Harris, Pickover, Reid, Saleh and Taylor 2002). I also bear in mind the spectral imagery and haunting central to Derrida's conception of the archive, beautifully reworked by Harris (2002), and recapitulated at the VIADUCT platform (Harris 2015), calling for attentive listening for the ghosts of people who were marginalised in their lifetime. In the second section of the paper I turn to questions of how the RMF campaign has been received and understood in terms of the archive of iconoclasm (Enwezor 2008). ${ }^{3}$ 


\section{Monuments - Taking Down the Sacred}

The field of study around monuments is well served by local and international literature. Perhaps, the most interesting are the psychological analyses, particularly of monuments that represent historical figures and their relationship with the living beings who occupy the peculiarly 'oppressive space' which these figures invariably project. (Hook 2005: 693). Derek Hook's primary subject is the now defunct monument of J. G. Strijdom in Pretoria dedicated to the apartheid prime minister, which Hook (2005: 699) uses to illustrate his contention that monuments are capable of radiating an impression of 'supernatural omnipresence'. Hook $(2005: 693,697)$ deploys Sigmund Freud's concept of the "uncanny" and Henri Lefebvre's emphasis on evaluating, as he puts it, the 'bodily experience' of constructed spaces to create a vivid sensation of the conditions of intersubjectivity between monument and spectator. Hook describes the care taken by the black maintenance workers not to be seen showing disrespect to the Strijdom bust, implying that, like the statue of the Tsar in October before its demise, the bust exercised its own power over and above that exercised by the state.

In an analysis of the reasons for the shocking destruction of cultural artefacts in Mali in 2012, Bhakti Shringapure (2015) uses the work of Georges Bataille on the subject of monuments to articulate what it is that makes them objects of fear and hatred to those who stand in a 'servile' position to them. Bataille (cited in Shringapure 2015) observes that: 'monumental productions are now the true masters ... gathering the servile multitudes in their shadows, enforcing admiration and astonishment, order and constraint.' Referring to cathedrals and palaces, but naming them as monuments, Bataille (cited in Shringapure 2015) claims that they 'speak and impose silence on the multitudes'. Following Bataille, Shringapure (2015) attributes to monuments the 'ability to command, prohibit, exclude and dominate'.

In a similar vein, discussing the destruction of Soviet era monuments in the "post-socialist" phase, Mikhail Yampolsky (1995) asks the reader to consider how subconsciously shocking it is even to see workers legitimately lay their hands on a monument because of the latter's quasi-sacred nature. Using Eisenstein's repetitive imagery of the destruction of the Tsar's statue, Yampolsky presents monument iconoclasm as a 'new fetishism', intending to endow it with the Freudian connotations of anxiety and (temporary?) triumph over the threat of castration. 
Katherine Verderey (1999) describes assaults on monuments as calculated acts to despoil their sacred character in order to bring them into the human realm. Notably, Chumani Maxele, whose flinging of human faeces at the Rhodes statue is supposed to have precipitated the 2015 campaign, is quoted by a fellow student as saying that he wanted the statue to feel 'ashamed, the same way he (Maxwele) feels ashamed that these feces [sic] are in his living environment' (Boroughs 2015), thus aiming to convert the statue from untouchable icon to sentient human being. It is worth recalling that Walter Benjamin's (cited in Linfield 2010: 17) argument that photography contributed to the 'desacralization of the world', which was one of the 'painful but necessary tasks', as he saw it, of modernity. In one of a series of photographs documenting the removal of the statue, the photographer, Schalk van Zuydam, captures a moment when the operation of lifting the statue from its plinth seems particularly delicate. The word "Fuck", painted in white graffiti on the base is clearly legible, and a mask-like layer of orange paint dumped over its head seems to obscure the statue's vision (Tshabalala 2015). The effect is to give it a strikingly human look of perplexity. In the RMF context, it might be proposed that photography added its weight to the students' endeavour to desanctify the statue.

Vocal members of the student body demonstrated familiarity with principal theorists of decolonisation, especially those who have written about spatial patterns of exclusion and injustice, notably Frantz Fanon. Shringapure (2015) argues that severe deprivation, material dispossession and the political exclusion that has long been visited on the Tuareg minority in Mali must bear some of the blame for the destruction of artefacts there, and turns to Fanon's (1961) image of - as Shringapure (2015) cites it - the 'colonized underclass' that watches from its segregated ghetto and longs to 'swarm the forbidden cities'. It is likely that Fanon's works were on the UCT students' campaign reading list. UCT student Kealeboga Ramaru observes: 'Symbolically what we've done is so powerful. We've brought this space where decisions are made without our consent and said: "Look this is our space too, and we deserve to be here"'(Ramaru 2015; see also Mbembe 2015).

Although the UCT protesters were not as violent as the iconoclasts in Mali whose actions Shringapure analyses, and the Rhodes statue is not even remotely as valuable as the artefacts destroyed in Timbuktu, the students articulated a similar 'cry for belonging' (Shringapure 2015). Perhaps not coincidentally, faeces-thrower, Maxwele uses the same 
formula when he says of the RMF campaign: 'it is a black cry, a cry of the workers, the cry of the staff and a cry from the students' (Bashton 2015).

It is likely that the protesters "addressed" the statue of Rhodes with visceral hatred (literally in the case of Maxwele) because they experienced it as continuing to exercise active power over their environment in the way that Hook and scholarly commentators cited above describe. At a particular moment, students overcame their habitual deference, and because it was cast in a realistic, albeit highly romanticised style, saw that the Rhodes statue was susceptible to being made human. This is the phenomenon that is graphically illustrated in October. At first, the statue of the Tsar appears impervious to attack, but once the sustained assault begins, it is revealed as vulnerable and proceeds to lose its head, which tumbles down in a grim parody of human execution. It might be argued that Eisenstein forged a template that has been, as I suggest below, hard to dislodge.

\section{As Archive?}

What then, I ask - since the literature on monuments and iconoclasm is rich - is to be gained from bringing readings of the archive/counter-archive to the RMF campaign? In attempting to answer that question, I turn to an essay on monuments from the pre-democratic era in South Africa by art historian and cultural critic, David Bunn (2002).

Through subtly anthropomorphising selected monuments, Bunn endows them with the gestures that postmodern theorists ascribe to the archive - showing them variously as duplicitous, mean-spirited, exclusive, phallocentric, elitist, and resistant to change. Among his subjects is the Rhodes Memorial on the slopes of Devil's Peak close to UCT, crammed with symbolism supposedly redolent of Rhodes's intellectual and physical prowess, as Paul Maylam (2005) documents, not a little sceptically. What is distinctive about Bunn's (2002) analysis is his Foucauldian-inspired argument that the Rhodes Memorial is an embodiment of 'pastoral power' (that is not overtly authoritarian), which characterised an aspect of British imperialism.

At this point, Bunn stops his appraisal of the Rhodes Memorial, leaving a suggestion for an analogy with the power exercised by the documentary archive as expounded by Hamilton et al. (2002). The Memorial is not simply an egocentric collage of symbols suggested by Rhodes 
himself (Bunn 2002; Maylam 2005), housed in a Greek-style temple designed by British architect Herbert Baker (1909), who believed that classical public buildings were the only match for what he saw as the vastness of the Cape mountain. It is also an instrument of the technology that defined colonial subjects, as much as did the Empire's paper records (see Stoler 2002). Given its high visibility, the Memorial was able to hail its subjects a great deal more loudly, although, to continue Bunn's conceit, not in the harsh, autocratic voice of the Afrikaner nationalist monuments that followed. The Rhodes Memorial's authoritarianism is less obvious, more diffuse and apparently benign.

Baker and Rhodes were members of a network described by Jeremy Foster (2008; see also Dubow 1997; Bates 2015) of upper class English supporters of the particular vision of "Reconstruction" espoused by Lord Alfred Milner and the civil service officials he recruited making up the so called "Kindergarten" in the years following the South African War. As Administrator of the two former Boer Republics, Milner was confronted with the ruination left in the wake of the War, and the still smouldering hostility between Boer and Briton. His programme of comprehensive reconstruction was intended to address both. It included the ideological promotion of a united white South African "nation" that would retain close ties with Britain - summed up in the paradoxical concept of "colonial nationalism". Those who fell outside the definition of "nation" would be excluded from direct representation and other rights of citizenship (Bunn 2002; see also Dubow 1997; Mabin and Smit 1997). As Foster (2008) argues, the visual landscape came to be heavily imbued with the programme of "colonial nationalism". Foster (2008: 40) asserts:

There is little doubt that the powerful afterlife enjoyed by Rhodes's vision and his own transformation into an inspirational figure for many colonial nationalists were mediated by the various memorials he caused to be constructed in South Africa before and after his death in 1902.

Baker was Rhodes's protégé. Rhodes had financed Baker's study tour abroad, which had fired the latter's imagination about architecture's capacity for making an indelible impression of 'dignity and power' on citizen and visitor alike (Baker 1909: 513) - and, ironically revealed to Baker where British metropolitan architecture had fallen lamentably short of its potential. According to Foster (2008), the legacy of colonial nationalism endured long after Milner's departure from South Africa in 1905. The Rhodes statue at UCT was sculpted by Marion Walgate and installed in 1934. She was the spouse of Charles Percival 
Walgate, who was employed by Baker's firm and was appointed to oversee the development of the buildings on the university campus (Bates 2015).

\section{The Photographic Archive}

Without extensive coverage in, first social and then mainstream media (Wakefield 2015), the campaign against the Rhodes statue would have made much less impact than it did. If there had been no images of Rhodes seated high up in his chair on the plinth, gazing towards a future materialising over the head of mere mortals below; of the crane heaving him off to obscurity; of a student dumping paint over his head; and of a group of students seizing the empty plinth, the affair would have faded quickly from view. It would undoubtedly have been less effective had there been no photographic imagery of what Henri Cartier-Bresson calls 'the decisive moment' (see O'Hagan 2014). As Sontag (2001: 3) guardedly remarks: 'photographs alter and enlarge our notions of what is worth looking at' (see also Barthes 2010: 34). Susie Linfield (2010: 22), writing against what she perceives to be Sontag's cynical tendencies, revealed in her denunciation of the proliferation of visual images as excessive, asserts: 'Photographs excel, more than any other form of art or journalism, in offering an immediate, viscerally emotional contact to the world.'

In On photography, Sontag (2001: 110) laments the effects of modern photography on its real-life subjects, on one hand depreciating them by making of them articles of consumption, and on the other inflating their value to that of an 'item for aesthetic appreciation' (see also Barthes 2010: 36, 118). Sontag's reservations are worth bearing in mind. But Sontag (2001: 53) also evokes something of the exhilaration of the 'quasi-accidental, quasi-magical' relationship of photographer and subject, mediated by a machine that is becoming 'ever more automated'. Since she made this observation, the technologies of photography have advanced spectacularly, and it is now possible for the photographer and subject to be the same person with much more facility than was the case forty years ago. In Camera lucida, Roland Barthes (2010 [1980]: 10) observes with an acuity that might have been born of an observation of selfie culture, except that he was writing decades before its advent: 'I constitute myself in the process of "posing", I instantaneously make another body for myself, I transform myself in advance into an image.' 
Many photographs from the RMF campaign show students posing for the cameras with the kind of keen visual and corporeal anticipation to which Barthes refers (for example, Gevisser 2015; Tshabalala 2015). They often look directly towards cameras visible in the photograph, and their declarative gestures seem calculated to make the greatest possible media impact. In some cases, a student taking her own photograph can be seen looking over at the photographic apparatus of a neighbour, perhaps to compare results or in a kind of joint affirmation (for example, Gevisser 2015; Tshabalala 2015; Kenny 2015; Mail Online 2015). Strikingly, UCT Fine Arts student, Sethembile Msezone (cited by Buist 2015), who created a performance piece representing the Zimbabwe Bird - also as she explains 'wrongfully appropriated by the British colonialist' - says that she had timed the raising of her arms (since she had her back to the action) by looking at 'the reflection of the statue coming down' in the sunglasses and cell phones of people standing in front of her. Her description evokes the distinctions Fred Ritchin (2009) makes between analogue and digital photographs, emphasising the almost infinite possibilities, not only for modification and reassembly of the pixels in digital photographs, but also for creating simultaneous alignments between different segments of real time. Msezone makes an easy passage between the reflection of the real event and her creative elaboration on it, which would have been impossible without the digital cameras incorporated into the multitude of cell phones raised to record the removal of the statue going on behind her. This arresting cameo could provide an entry point for considering what the implications of hypertravel (to borrow from, and slightly change Ritchin's original wording) are for the archive.

Msezone used digital image capture by which to time her choreography. She also discovered the extent of the impact of her performance only later through seeing its coverage on Facebook (Buist 2015), thus at one remove from her real time audience - in a kind of ironic twist of digitisation that otherwise allows for so much unprecedented immediacy. The students were canny makers and users of visual media as a media survey by Media Tenor SA of 50 articles published in March 2015 testifies: 'A group students at UCT have generated high volumes of coverage on the statue' (Wakefield 2015). Furthermore, the journalist reporting on the survey observes that the Media Tenor study, which also included a less systematic review of 'hundreds of blogging platforms', found that the South African media had been a major player in setting the agenda for the RMF debate (ibid.). 
One of Michael Hammond's photographs (Calata 2015) published in UCT's Daily News appears to be a wry comment on the centrality of the role of the media in the campaign. In the bottom right hand corner is a cell phone with its owner only partially visible, her thumb raised about to tap out a message. A black woman in profile looks on from the left corner, and there are groups of students on what the caption identifies as the 'Jammie' Plaza - the open square in front of UCT's landmark Jameson Hall named for Rhodes' most notorious, yet risible colleague, Leander Starr Jameson. There is no sign of the statue, which stood in perfect alignment with the 'space between the third and fourth pillars of the Jameson Hall', one hundred metres beyond the Plaza (Ndebele 2013). The wording on a banner in the centre of the photograph, punnily claiming that: 'All Rhodes lead to colonisation of the Mind' is partially obscured by three photographers with tripods. It is reminiscent of Don Delillo's (2011) most photographed barn in America. As the novel's protagonist discovers, the famous barn does not exist. Is it possible that the vast and still live photographic archive of the RMF campaign has made it more difficult instead of easier to see the barn?

\section{The Nature of the Archive?}

In attempting to determine what kind of counter-archive is in the process of being generated, I examined a sample of photographs disseminated principally in the mainstream and official campus media. As noted, the quantity of images produced during the course of the campaign is vast and a more comprehensive analysis, including those posted on social media would take many months. Thus, I offer my comments as suggestive and in the spirit of inviting debate. My analysis has benefitted from the distinction Barthes makes in Camera lucida (2010) between his two neologisms: 'studium' and 'punctum', explained below.

An overwhelming number of the images produced by a Google search that I ran between the $10^{\text {th }}$ and $12^{\text {th }}$ of June 2015 , which had appeared in international mainstream media, were taken by Schalk van Zuydam, evidently having been sourced from Associated Press (AP). There is also a range of photographs from other agencies, including Getty Images and Agence France Presse (AFP). All the images are generally more sophisticated and subtle than the stock images from Getty analysed by David Machin (2004), leading him to conclude that the market imperative determines a high level of conformity, and dulls or trivialises the meaning of central concepts like "work" or "freedom". 
While it would not be right to say that the photographs 'banalise' their subject matter (Barthes 2010: 118; see also Sontag 2001), some of the Getty images for the RMF campaign seem to fall into a "trope", in the sense advanced by Marta Zarzycka and Martijn Kleppe (2013) in their study of winning photographs over a three-year period of the competition hosted by the World Press Photographic Foundation. In the RMF case, it would unfortunately be a trope of African savagery. For example (Kenny 2015), a young black man dressed in a loincloth is shown holding a chain, as he celebrates victory with his colleagues on top of the empty plinth. It is probable that he was a participant in a performance piece around the story of Sarah Baartman's purchase and exhibition in Europe in the early nineteenth century (Naidoo 2015), but without the contextual information, the photograph connotes barbarism. Its effect is reinforced by the accompanying text by aggrieved former white UCT student and lecturer, Andrew Kenny, which attracted blatantly racist feed. Another of the Getty images (Boroughs 2015) shows a young black woman with long braids, screaming and raising her forearm. The foreshortening of the arm exacerbates the impression of unbridled aggression. But the photograph is more complicated to decode than it initially appears. The hand of the raised arm is configured into the international gesture for "I love you", and the photograph was selected to run alongside a text that pays respectful attention to student leader, Kgotsi Chikane's complaint about the 'norms and values of institutionalised racism' (Boroughs 2015).

Thus, it is not easy to come to any definitive conclusions about the images sourced from the agencies, especially given the limited scope of my research. But I would like to consider what an application of Barthes' concepts of studium and punctum offer in the way of a preliminary answer to the question prompted by Delillo's fictional rendition of the most photographed barn in America, with which I ended the last section. Ultimately, after the furious clicking of shutters (many of them digital) and the exuberant sharing of images, what remains of the subject?

Most of Van Zuydam's photographs seem to fit Barthes' category of studium (pertaining to information and knowledge). It would be unjust, as I have suggested, to categorise them with the shallow tropes deplored by Machin (2004), and to some extent, Zarzycka and Kleppe (2013), Sontag (2001), Roberts (2009) and Barthes (2010). The Van Zuydam photographs were probably sourced because picture editors thought they would attract potential consumers, but his photographs also offer rich information about the specific 
context and event. The question I asked, following roughly in the methodological footsteps of Zarzycka and Kleppe (2013), after I had concluded that the photographs in mainstream media are mostly studium-orientated was, do they possess the more deeply affecting, and therefore, presumably lasting traits, amounting to what Barthes calls punctum? Punctum, Barthes (2010: 27) writes is: 'this element which rises from the scene, shoots out of it like an arrow, and pierces me.' As Barthes says, in pre-emptive defiance of his scholarly audience, what counts as punctum is bound to be subjective; his examples are all of tiny, seemingly peripheral details - the folded arms of a brother excluded from an embrace or the bandage on the finger of a mentally challenged girl (ibid. 52, 50).

Alternatively, John Roberts (2009) offers an idea called 'lateness', meaning a sense of immediate memorialisation achieved by a certain kind of photograph that comes too late to document the principal action, and is left with its traces - a whiff of smoke after the bombing, the empty battlefield. Perhaps Van Zuydam's series of the statue lifting unsteadily from its plinth with an anxious workforce poised beneath it (for example, Tshabalala 2015), and the way he has caught the statue's face covered with an orange glaze from paint, counts as something like lateness. The protesters have already succeeded in destroying Rhodes' complacency, the effects of which are far-reaching, possibly dangerous. The crane images might be read as saying that everything still hangs in the balance. Under a headline whose wording suggests memorialisation (and therefore lateness in Roberts's sense), 'Rhodes Goes Quietly Amid Jubilation', the authors (Omar, Swinger and Calata 2015) describe the statue's motion as 'it swivelled east and west moments before coming to rest on the back of a flatbed truck'. Van Zuydam's crane series (Mail Online 2015) successfully captures the reported motion of the statue, seemingly filled with trepidation, taking a last look around its old precinct as it is hauled off to an undisclosed destination. There might be punctum too in Van Zuydam's photograph of the statue when it was still in place against the backdrop of the mountain, radiating a broad halo effect (for example, Laing 2015). After looking at it for some time, I conceded that I felt punctum emanating from the slight hand raised above the chest of a lone black student burdened by his enormous backpack, passing by on the steps below.

The photographs sourced from the agencies are usually of the studium variety with very little punctum. But they should probably best be understood, as Paul Weinberg (2015) remarked to me, as addressed to viewers who are not familiar with the UCT campus. Many 
of the photographs in mainstream media are accomplished, and perhaps they do move different audiences in ways that they fail to move me. However, they invariably fit the Eisenstein template as represented in the famous scene from October discussed above. It may well be, that in trying to capture the event for viewers without contextual knowledge, this template becomes ineluctable. Perhaps the fact that the real model for Eisenstein's statue of the Tsar was removed by official decree rather than having been smashed up by the avenging 'proletariat' makes his scene even more appropriate as a template for images of the Rhodes statue, which despite some superficial disfigurement, was not destroyed but sent off for indefinite preservation.

While acknowledging that they are enabled by the viewers' familiarity with the UCT campus, I maintain that there are some examples of punctum in the photographs published in South African media. I take two examples. One (Transform UCT 2015a) shows the head of a black woman in soft focus, about to pass underneath a poster stuck crudely onto the wall of a university building that reads: 'Beware of Racist Symbols on Campus'. As it strikes, the punctum generated by the tattered remains of older posters still clinging to the wall produces in me a wistfulness for all the generations that failed in their struggles against racism and whose legacies are barely visible. The second example of punctum occurs in a photograph (Transform UCT 2015b) of two banners being held up by students under the ragged clouds of an autumn sky, with groups of students in the foreground, some wearing Economic Freedom Fighters (EFF) berets. The mountain and ivy covered university buildings recede into the background. One of the banners reads: 'Black Pain is not Negotiable', and the other (the one that for me, creates the punctum effect) is unreadable because the viewer is looking at it from the reverse side.

\section{Conclusion}

I have argued that the application of theory generated around the archive in approximately the last twenty years, which was forcefully expressed the 2015 VIADUCT platform, provides a keener appreciation of the function of the Rhodes statue in relation to power, both at the time of its creation and in the contemporary moment. It also seems that the protesters involved in the RMF campaign drew on the vast archive of monument iconoclasm, while consciously extending and elaborating on it to make their own. It is difficult to reach conclusions, especially about what may be called the counter-archive of the RMF campaign 
since it is still so volatile. It is rich in contextual information, featuring a variety of voices and images capable of piercing viewers to the heart. Whether or not it will prove to be a counter-archive that shifts the dominant epistemological paradigm is a question that, like Rhodes at the end of the crane lever, hangs in the balance.

\section{Acknowledgments}

I extend my very warm thanks to Leora Farber and Claire Jorgensen; Fernanda Derntl and the Faculty of Architecture at the University of Brasilia; Alan Mabin, Georges Pfruender, Paul Weinberg and Natasha Christopher; and to the referees.

\section{Notes}

${ }^{1}$ See the usually extremely perspicacious Justice Malala (2015) describing the students as 'mumb(ling) incoherently' through the statue debate.

${ }^{2}$ I read Okwui Enwezor (2008) only after recording the similarities. The fact that Enwezor picks up the same similarities in a Romanian documentary about the revolution entitled Videograms (2003) reinforces my point about the influence of the visual archive.

${ }^{3}$ Enwezor remarks on Michel Foucault's (1972) observation about the changes in the nature of the discipline of history, summarising a complicated argument about the move from turning monuments into documents into turning documents into monuments.

\section{References}

Art Daily. 2015. Pro-Russians Blast Destruction of Monuments to Three Bolshevik Heroes in Ukraine. Artdaily.org, artdaily.com/news/77830 (accessed 25 May 2015).

Baker, H. 2009. The Architectural Needs of South Africa.

repository.up.ac.za/bitstream/handle/2263/675/Baker article.pdf (accessed 11 June 2015).

Barthes, R. 2010 [1980]. Camera lucida. Trans. R. Howard. London: Vintage.

Bashton, J. D. 2015. UCT in Politics. Rhodes Must Fall, 20 March. jdbashton.com/uct-in-politicsrhodes-must-fall (accessed 8 June 2015).

Bates, A. 2015. No Longer Watching over Heath or Man. Your Sculpture, 9 March. https://yoursculpture.wordpress.com 2015/05/28, no-longer-watching-over-man-or-heath (accessed 11 June 2015).

Boroughs, D. 2015. Why South African Students Say the Statue of Rhodes Must Fall. kbs.org/news/2015/mar/28/why-south-african-students-say-rhodes-must-fall (accessed 18 May 2015). 
Buist, E. 2015. Sethembile Msezane performs at the fall of the Cecil Rhodes statue 9 April. The Guardian 15 May. www.theguardian.com/artanddesign/2015/may15/sethembile-msezane-performsat-the-fall-of-the-cecil-rhodes-statue (accessed 12 August 2015).

Bunn, D. 2002. Whited sepulchres: on the reluctance of monuments. In Blank: apartheid architecture and after, ed. H. Judin and I. Vladislavić, [Sp.]. Rotterdam: NAi Publishers.

Calata, A. 2015. Give us another space, says Rhodes Must Fall. Daily News. www.uct.ac.za/dailynews/?id9103.

Daily News 2015. Photograph by Yusuf Omar. 9 April. UCT's Rhodes statue to be removed at 17 h00 today. www.uct.ac.za/dailynews/?id=9097 (accessed 9 August 2015). I think should be removed think I took him out of the text - please double check.

Delilo, D. 1986. White noise. London: Penguin.

Dubow, S. 1997. Colonial nationalism, the Milner Kindergarten and the rise of South Africanism, 1902 -10. History Workshop Journal 43: 53-85.

Enwezor, O. 2008. Archive Fever: Photography between History and the Monument. artistes.ucsc.edu/Daniel/public_record/okwuienwezor (accessed 13 June 2015).

Fanon, F. 1961. The wretched of the earth: a Negro psychoanalyst's study of the problems of racism and colonialism in the world today. New York: Grove Press.

Farber, L. and C. Jorgensen. 2015. Framing statement, VIADUCT 2015 platform programme, Archival addresses: photographies, practices, positionalities. Visual Identities in Art and Design Research Centre, University of Johannesburg, 18-20 March.

Foster, J. 2008. Washed with sun: landscape and the making of white South Africa. Pittsburgh: University of Pittsburgh Press.

Foucault, M. 1972. The archaeology of knowledge. https://www.marxist.org/reference/subject/philosophy/works/fr/Foucault.html (accessed 14 June).

Gevisser, M. 2015. South African students must take movement to society for real progress. Los Angeles Times 18 April. www.latimes.com/opinion/op-ed/la-oe-0419-gevisser-rhodes-20150419story-html (accessed 7 August 2015).

Gye, H. 2015. Marine pictured pulling down statue of Saddam in Baghdad questions point of Iraq War 10 years after invasion. USA-UK Online. www.usukonline.com (accessed 18 May 2015).

Hamilton, C. and V. Harris, M. Pickover, G. Reid, R. Saleh and A. Taylor. eds. 2002. Refiguring the archive. Cape Town: David Philip.

Hamilton, C. 2015. Lines of sight: archives, counter-archives, and the revisioning work of crossmedium archival engagements. Paper presented at the VIADUCT 2015 platform, Archival addresses: photographies, practices, positionalities. Visual Identities in Art and Design Research Centre, University of Johannesburg, Johannesburg, 18-20 March.

Harris, V. 2002. The archival sliver: power, memory and archives in South Africa. Archival Science 2 (12): 63-86. 
Harris, V. 2015. Hauntology, archivy and banditry. Paper presented at the VIADUCT 2015 platform, Archival addresses: photographies, practices, positionalities. Visual Identities in Art and Design Research Centre, University of Johannesburg, 18-20 March.

Hodes, R. 2015. The Rhodes Statue Must Fall: UCT's Radical Rebirth. Daily Maverick 13 March. www.dailymaverick.co.za/article/2015-03-13-the rhodes-statue-must-fall (accessed 18 May 2015).

Holder, T. 2015. [Video]. Eyewitness News. ewn.co.za/2015/03/19/UCT-students (accessed 8 June 2015).

Hook, D. 2005. Monumental spaces and the uncanny. Geoforum 36(6): 688-704.

Hollier, D. 1992. Against architecture: the writings of Georges Bataille. Trans. B. Wing. Cambridge, Massachusetts: MIT Press.

Kenny, A. 2015. The students tearing down Cecil Rhodes's statue are still upholding his legacy. The Spectator 25 April. www.spectator.co.uk/features/9507562 (accessed 12 August 2015).

Laing, A. 2015. Students pelt colonialist Cecil Rhodes' statue with excrement. The Telegraph, 17 March.

www.telegraph.co.uk/news/worldnews/africanandindianocean/southafrica/11478634/students-peltcolonialist-cecil-rhodes-statue-with-excrement (accessed 9 August 2015).

Linfield, S. 2010. The cruel radiance: photography and political violence. Chicago: University of Chicago Press.

Mabin, A. and D. Smit. 1997. Reconstructing South Africa's cities? The making of urban planning 19002000. Planning Perspectives 12(2): 193-223.

Machin, D. 2004. Building the world's visual language. Visual Communication 3(3): 316-336.

Mahapa, R. 2015. Rambina Mahapa on the Rhodes Must Fall Movement.

https:www.youtube.com/watch?v=uAe/JDep2 (accessed 7 June 2015).

Mail Online. 2015. South African university removes statue of colonialist. 9 April. www.dailymail.co.uk/wires/ap/article-3032509/South-Africa html (accessed 7 August 2015).

Maylam, P. 2005. The cult of Rhodes: remembering an imperialist in Africa. Cape Town: David Philip.

Mbembe, A. 2015. Decolonising Institutions. Mail and Guardian. Multimedia/2015-08-06decolonising-institutions-achille-mbembe (accessed 10 August 2015).

Naidoo, L-A. 2015. Decolonising Institutions. Mail and Guardian. Mg.co.za/2015-08-06-decolonisinginstitutions-leighann-naidoo (accessed 10 August 2015).

Ndebele, N. 2013. Reflections on Rhodes: A story of time. Daily News November. Published as introduction to Weinberg, P. ed. 2013. Viewpoints: The university and its treasures. Cape Town: UCT Press. www.uct.ac.za/dailynews/?id=9038 (accessed 7 August 2015).

O'Hagan, S. 2014. Cartier-Bresson's Classic is Back - but his Decisive Moment has Passed. www.the guardian.com/artanddesign/2014/dec/23 (accessed 24 May 2015).

Omar, Y., H. Swinger and A. Calata. 2015. Rhodes goes quietly amid jubilation. Daily News 9 April. www.uct.ac.za/dailynews/?id=9098 (accessed 9 August 2015).

Petersen, C. 2015. Final Call on Rhodes Today. Cape Times 8 April. 
www.iol.co.za/capetimes/final-call-on-rhodes-today (accessed 19 August 2015).

Ramaru, K. 2015. Rhodes Must Fall: The University must be Decolonised. The Daily Vox 7 April. www.thedailyvox.co.za/rhodes-must-fall (accessed 7 June 2015).

Ritchin, F. 2009. Toward a hyperphotography. After photography.

Sites.uci.edu/01807w14/files/2014/02/ritchinfred_Towardahyperphotography.pdf (accessed 12 August 2015).

Roberts, J. 2009. Photography after the photograph: event, archive and the non-symbolic. Oxford Art Journal 32(2): 281-298.

Shringapure, B. 2015. Rage against the Monuments. Warscapes.

www.warscapes.com/opinion/rage-against-the-monuments (accessed 25 May 2015).

Sontag, S. 2001. On photography. New York: Picador.

Stoler, A-L. 2002. Colonial archives and the arts of governance. Archival Science 2: 87-109.

Taylor, A. 2011. 20 years Since the Fall of the Soviet Union. In Focus 23 December. www.theatlantic.com (accessed 18 May 2015).

Transform UCT. 2105a. Photograph by Je'nine May, Daily News 9 April. www.uct.ac.za/news/Transform-UCT (accessed 9 August 2015).

Transform UCT. 2015b. The future is watching. Photograph by Roger Sedres. Daily News 13 April. www.uct.ac.za/dailynews/?id=9102 (accessed 9 August 2015).

Tshabalala, S. 2015. When Cecil Rhodes' statue fell it laid bare South Africa's transformation challenges. Quartz 10 April. Qz.com/381152/when-cecil-rhodes-statue-fell-it-laid-bare-south-africa'stransformation-challenges (accessed 7 August 2015).

Verderey, K. 1999. The political lives of dead bodies: reburial and postsocialist change. New York: Columbia University Press.

Wakefield, A. 2015. Transformation, redress, dominate Rhodes debate - study News 247 April. www.news24.com/South Africa/news/transformation-redress-dominate-rhodes-debate 20150407 (accessed 9 August 2015).

Weinberg, P. 2015. Personal communication with the author, 12 August.

Yampolsky, M. 1995. In the shadow of monuments: notes on iconoclasm and time. In Soviet hieroglyphics: visual culture in late twentieth-century Russia, ed. N. Condee, 93-112. Bloomington: Indiana University Press.

Zarzycka, M. and M. Kleppe 2013. Awards, archives and affects: tropes in the World Press Photo Contest 2009-11. Media, Culture and Society 35(8): 977-995. 